\title{
Learners in the marketplace: Ethical and educational dilemmas
}

\author{
Authors: \\ Elize C. du Plessis ${ }^{1}$ \\ Petro Marais ${ }^{1}$ \\ Affiliations: \\ ${ }^{1}$ College of Education, \\ University of South \\ Africa, South Africa \\ Corresponding author: \\ Elize du Plessis \\ Email: \\ dplesec@unisa.ac.za \\ Postal address: \\ PO Box 392, University of \\ South Africa 0003, \\ South Africa \\ Dates: \\ Received: 05 July 2011 \\ Accepted: 12 June 2012 \\ Published: 16 Nov. 2012 \\ How to cite this article: \\ Du Plessis, E.C. \& Marais, \\ P., 2012, 'Learners in the \\ marketplace: Ethical and \\ educational dilemmas', \\ Koers - Bulletin for Christian \\ Scholarship 77(1), Art. \#48, \\ 7 pages. http://dx.doi. \\ org/10.4102/koers.v77i1.48

\section{Note:} \\ This article was developed \\ from a paper delivered at \\ the Koers-75 Conference on \\ 'Worldview and Education', \\ held in Potchefstroom, South \\ Africa, from 30 May to 02 \\ June 2011. \\ Hierdie artikel is ' $n$ verdere \\ ontwikkeling van ' $n$ \\ voordrag gelewer by die \\ Koers-75 Konferensie oor \\ 'Worldview and Education' \\ in Potchefstroom, Suid- \\ Afrika, vanaf 30 Mei tot 02 \\ Junie 2011
}

(C) 2012. The Authors. Licensee: AOSIS OpenJournals. This work is licensed under the Creative Commons Attribution License.
Since the abolishment of legislation (the South African Schools Act, No. 84 of 1996) stipulating that a learner may only attend a certain school in an area, there is great competition amongst schools to attract learners to their schools. There is a tendency to regard as commodities learners who can be seen as assets to the school, especially if these learners show a talent for sports and have outstanding sporting achievements. The main aim of the research was to determine whether school principals, learners and parents think that it is unethical to 'buy' talented learners. A qualitative research approach was undertaken to determine the views of a purposefully selected sample of school principals, learners and parents regarding the 'buying' of talented learners. These participants were chosen as they were important role players in the process of 'buying' talented learners. Data were collected by means of a questionnaire with semistructured and open-ended questions. The participants' answers were critically analysed, and the ethical correctness was determined by evaluating them against the ethical ideas identified in five ethical approaches, namely the utilitarian approach, the rights approach, the fairness or justice approach, the virtue approach and the ethical problem solving approach. An extrapolation of these findings gives one an idea of our society's attitude to the 'buying' of talented learners and whether a need exists to actively create greater awareness of this practice. The findings are significant to illustrate the different viewpoints of school principals, talented learners and parents on the ethical and educational dilemmas of schools that 'buy' talented learners.

Leerders in die markplein: Etiese en opvoedkundige dilemmas. Sedert die afskaffing van wetgewing (die Suid-Afrikaanse Skolewet, Nr. 84 van 1996) wat bepaal dat 'n leerder net na 'n sekere skool in 'n area mag gaan, het daar groot kompetisie tussen skole ontstaan om leerders na hul skole te lok. Die tendens het ontstaan om leerders wat 'n aanwins vir die skool kan wees as handelsitems te beskou, veral as hierdie leerders ' $n$ talent toon vir sport en uitstekende sportprestasies lewer. Die hoofdoel van die navorsing was om te bepaal of skoolhoofde, leerders en ouers reken dat dit oneties is om talentvolle leerders te koop. ' $\mathrm{n}$ Kwalitatiewe navorsingsbenadering is gevolg om die standpunte van ' $\mathrm{n}$ doelgerigte, geselekteerde steekproef van skoolhoofde, leerders en ouers te bepaal betreffende die 'koop' van talentvolle leerders. Hierdie deelnemers is gekies omdat hulle belangrike rolspelers is in die proses wanneer talentvolle leerders 'gekoop' word. Data is verkry met behulp van ' $n$ vraelys met semi-gestruktureerde en oop vrae. Die deelnemers se antwoorde is krities geanaliseer en die etiese korrektheid daarvan is bepaal deur dit te evalueer in ooreenstemming met die etiese idees soos geïdentifiseer in die vyf etiese benaderings, naamlik (1) die nuttigheidsbenadering, (2) die regte-benadering, (3) die regverdigheidsbenadering, (4) die Deugdebenadering en (5) die etiese probleemoplossingsbenadering. ' $n$ Uitbreiding van hierdie bevindinge gee ' $n$ idee van 'n gemeenskap se houding oor die 'koop' van talentvolle leerders en dien ook om vas te stel of daar ' $n$ behoefte tot groter bewustheid van hierdie praktyk bestaan. Die bevindinge is belangrik om die verskillende uitgangspunte van skoolhoofde, talentvolle leerders en ouers rakende etiese en opvoedkundige dilemmas van talentvolle leerders wat 'gekoop' word, te illustreer.

\section{Introduction}

According to an article in Beeld (Oosthuizen 2009:2), 80\% of Grade 12 learners failed Mathematics in 2009. Oosthuizen (2009:2) asks the question: 'How many schools have bought scholars for sport and pay all expenses, whilst the academic side is suffering?' Oosthuizen's plea is thus to employ more good teachers and fewer professional sports coaches. Oosthuizen's article verbalises the current tendency to draw learners who can be seen as assets to the school as commodities, especially if those learners show a talent for sports and have outstanding sporting achievements. This tendency issued forth after the South African Schools Act, No. 84 of 1996, abolished the stipulation that a learner may only attend a certain school in an area. 
Whilst Oosthuizen questioned whether the 'buying' of learners is detrimental to the academic activities of schools, the authors of this article aim to address the morality of this practice. This article makes use of a qualitative study undertaken by the authors, in which the views of school principals, learners and parents on the moral and educational correctness of such transactions are determined and analysed. The first step in analysing a moral issue is to 'get the facts'. This first step is amongst the most important and the most frequently overlooked (Velasquez-Dirksen et al. 2011:1-4). Having the facts is not enough, though. Facts by themselves only tell us what is; they do not tell us what ought to be. In addition to getting the facts, resolving an ethical issue also requires an appeal to values.

The question of values, specifically which values are appropriate, will be addressed via a theoretical framework consisting of five ethical approaches. These five ethical approaches form an accepted ethical model (Velasquez-Dirksen et al. 2011:1-4). The researchers analysed each of these approaches in terms of what is objectively right and good. By its very nature, the objectively right and good is biblically correct and is written by God on the hearts of all people (see Rm 2:15). Thus, according to the authors, the Christian perspective (which also forms part of the authors' worldview) is based on the belief in objective, absolute moral truth and such truth corresponds to Biblical moral injunctions.

This article will firstly set out the above-mentioned theoretical framework. This framework is based on five approaches, namely the utilitarian approach, the rights approach, the fairness or justice approach, the virtue approach and the ethical problem-solving approach. Each of the five ethical approaches will be discussed critically. The questions posed to participants in the qualitative study arose from this framework.

The main aim of the research was to determine whether school principals, learners that have been 'bought' and parents think that it is unethical to 'buy' talented learners. The participants' answers were analysed critically, and the moral correctness was determined by evaluating them against the morally correct ideas identified in the five ethical approaches. Extrapolating these findings gives an idea of a society's attitude to the buying of talented learners and whether a need exists to actively create greater awareness of this practice.

In the following section, the theoretical framework for this article is discussed. Thereafter, the research design and data-analysis are presented, followed by a discussion of the findings and a final conclusion.

\section{Theoretical framework}

Theoretical frameworks serve as epistemological guides that help to interpret the knowledge presented in a study
(Agherdien 2009:ii). The theoretical framework used in this study is an accepted model and is used as the basis for many programmes at the Markkula Centre for Applied Ethics (Velasquez-Dirksen et al. 2011:1-3). This model consists of five approaches, namely the utilitarian approach, the rights approach, the fairness or justice approach, the virtue approach and the ethical problem-solving approach. After discussing each approach in this model, the authors will use it as a lens to evaluate the participants' viewpoints regarding the ethical and also the educational dilemmas that arise when talented learners are 'bought'.

\section{The utilitarian approach}

Utilitarianism was conceived in the 19th century by Jeremy Bentham and John Stuart Mill to help legislators determine which laws were morally best. Both Bentham and Mill suggested that ethical actions were those that provide the greatest balance of good over evil (Velasquez-Dirksen et al. 2011:1-3; Jimenez 2008:59-68; Arrow 1971:409-415).

To analyse an issue using the utilitarian approach, the various courses of action available should first be identified. The following questions should be asked: Who will be affected by each action and what benefits or harms will be derived from each? Then one should choose the action that will produce the greatest benefits and the least harm. The ethical action is the one that provides the greatest good for the greatest number (Velasquez-Dirksen et al. 2011:1-3).

This approach appears to be and often is praiseworthy. Nevertheless, it is not an objective, absolute, moral truth. Problematic in this approach is that one can vindicate any action (also immoral, evil actions) as ethical if the greatest number of persons benefit from this action. Secondly, harm against minorities is justified if such harm benefits or appears to benefit the majority. This is contrary to a biblical approach.

\section{The rights approach}

The rights approach to ethics has its roots in the cognitive developmental approach developed by Kohlberg (1971). This approach assumes that the instruction of values is an intellectual (cognitive) process, based on the active structuring of active patterns of thought and that there is an upward movement from one cognitive level to the next (Maduane 1992:115-123). Kohlberg distinguishes between three levels of cognitive moral development with two stages at every level, which tallies to a total of six age-related stages of cognitive moral development. The aim of morality in Kohlberg's approach and the rights approach is presented by progress from a present stage of moral reasoning to the next one. It is assumed that learners can and thus have the right to make their own value-based decisions after moral instruction. In every stage of moral instruction, learners are exposed to problem situations, and they must reason about the situation by pointing out and applying appropriate values. The solutions are then connected to the next stage of reasoning ability (Brady 1990:13; Wright 1982:25). 
The rights approach can actually be traced back to Immanuel Kant (1970:295). He believed moral laws could be discovered purely through reasoning. Kant (1970:324) formulated a 'supreme' moral law: Act as if the maxim of thy action were to be by thy will a universal law of nature. According to Horn (1996:101-102), this maxim of Kant issued forth into relativism and subjectivism. Both relativism and subjectivism form the basis of the idea that individuals have a fundamental right to choose what they will do with their lives, and they have a fundamental moral right to have their choices respected (Velasquez-Dirksen et al. 2011:2-3).

Other different but related rights, besides this basic one, are also formulated. These other rights (an incomplete list follows below) can be thought of as different aspects of the basic right to choose what we want to do with our lives:

- The right to the truth: We have a right to be told the truth and to be informed about matters that significantly affect our choices.

- The right to privacy: We have the right to do, believe and say whatever we choose, providing we do not violate the rights of others.

- The right to what is agreed: We have a right to what has been promised by those with whom we have freely entered into a contract or agreement. (Velasquez-Dirksen et al. 2011:2-4)

In deciding whether an action is moral or immoral using the rights approach, the following question is important: 'Does the action respect the moral rights of everyone?' Actions are wrong to the extent that they violate somebody's rights; the more serious the violation, the more wrongful the action (Velasquez-Dirksen et al. 2011:2-4).

The problem, however, is that the rights approach stands or falls with the idea that rights are universal moral laws that everybody ought to obey. This refutes the idea of the individual as an autonomous, free moral agent. This internal inconsistency arises from the fact that the rights are not grounded in an objective authority, transcendent and outside of humanity (Brown 1990:326). What is lacking in the rights approach is the individual's higher obligation to God, or a god. Brown (1990:325) and MacIntyre (1981:45) point out that Kant's moral maxim does not explain why one should act unselfishly since it does not appeal to a transcendent, absolute authority. Without solid grounds, the individual, as a free moral agent, can act only in his or her own interests (MacIntyre 1981:45). Furthermore, Brown (1990:325-326) explains that, if any right is a morally binding law, it would have to be 'the expression of the recognition of a moral obligation which comes from outside us'. Thus, again one sees that the idea of humans as autonomous, free moral agents is refuted.

\section{The fairness or justice approach}

The fairness or justice approach to ethics has its roots in the philosophy of the ancient Greek philosopher, Aristotle (MacIntyre 1981:50). In this approach, the basic moral questions are: How fair is an action? Does it treat everyone in the same way, or does it show favouritism and discrimination?
People should, of course, all be treated fairly, justly and equally. Favouritism is wrong. It gives benefits to some people without a justifiable reason for singling them out. Discrimination imposes burdens on people who are no different from those on whom burdens are not imposed. Velasquez-Dirksen et al. (2011:2-4) also evaluate favouritism and discrimination to be unjust and wrong. Their evaluation is in line with a biblical approach to ethics, according to which all people should be treated fairly, justly and equally. Unfortunately favouritism and discrimination can be legitimised. Such legitimisation is described by George Orwell in his novel Animal Farm (1990).

\section{The virtue approach}

The virtue approach to ethics assumes that there are certain ideals to which we should strive and which facilitate the full development of our humanity. These ideals are discovered through thoughtful reflection on what kind of people we have the potential to become (Velasquez-Dirksen et al. 2011:3-4; Jimenez 2008:59-68; Arrow 1971:409-415). However, this can become meaningless without an appeal to a higher authority outside and above the self.

Virtues are attitudes or characteristics that enable us to live and to act in ways that allow us to develop our highest potential. They enable us to pursue our ideals. Honesty, courage, compassion, generosity, fidelity, integrity, fairness, self-control and prudence are all examples of virtues. Virtues are like habits: Once acquired, they become characteristic of a person. Moreover, a person who has developed virtues will hopefully be disposed to act in ways consistent with his or her moral principles. The virtuous person is the ethical person. In dealing with an ethical problem using the virtue approach, the following questions may be asked (Velasquez-Dirksen et al. 2011:2-4): What kind of person should I be? What will promote the development of my character and my community?

Like Plato, Aristotle (1989) regards the ethical virtues (justice, courage and temperance) as emotional and social skills that should be developed as moral virtues. What is needed in order to live well is a proper appreciation of the way in which aspects such as virtue and honour fit together as a whole. Ethical wisdom cannot be acquired solely by learning general rules. Through proper upbringing and habits, learners develop practical skills that enable them to put their broad understanding of wellbeing into practice in ways that are appropriate to each occasion.

The Christian perspective meshes well with the virtue approach but with the addition of the individual's higher obligation to God. In a theistic framework, the individual is not morally autonomous but must base moral decisions on objective moral virtues. Examples of objective moral virtues are honesty, impartiality, courage, self-control, responsibility, concern for others, mercy and justice (Lewis 1946:56). These virtues are taught by the religions and secular philosophies that maintain the existence of absolute truth. In these religions and philosophies, the ultimate objective grounding 
differs (Horn 1996:104). In Christianity the common, objective moral virtues are grounded in the character of Christ, who embodies biblical ethics. The common moral laws (all of which are also biblical) were compiled by C.S. Lewis (1946:56ff.) by consulting ancient and contemporary religions and philosophies.

\section{Ethical problem solving approach}

The previous four approaches are combined into a fifth approach, namely the problem solving approach. This approach to ethics suggests that, once one has determined the facts, one should ask the following four questions to resolve a moral issue via the ethical problem solving approach. In the research project, the authors also posed these questions to the participants:

- What benefits and what harms will each course of action produce, and which alternative will lead to the best overall consequences?

- What moral rights do the affected parties have, and which course of action best respects those rights?

- Which course of action treats everyone the same, except where there is a morally justifiable reason not to do so, and does not show favouritism or discrimination?

- Which course of action develops moral virtues?

These four questions formed the basis for the questions put to the participants. Thus, the research method amounted to the application of the ethical problem solving approach. Of course, this method cannot provide an automatic solution to moral problems. It is not meant to. The method in this study is meant to help identify some of the most important ethical dilemmas that arise when schools 'buy' talented learners. One should deliberate on moral issues, seeking truth and goodness, and keeping a careful eye on both the facts and on the ethical considerations of what is right and good (Velasquez-Dirksen et al. 2011:3-4). The participants' responses, that is, the data collected, comprise the facts, whilst the ethical considerations are guided by the researchers' discussions in sections to follow.

In answering the research questions, the authors' evaluative framework was informed by a Christian perspective, which included what is good in the other frameworks.

\section{Research methodology}

This study employed a qualitative research approach in order to gain insight (McMillan \& Schumacher 2006:26) into the views of school principals, learners and parents regarding the educational and ethical dilemmas of the practice of 'buying' learners to improve the image of the school. Purposeful sampling was used to select 11 information-rich participants. All the participants were from secondary schools in Gauteng. The participants were not asked to identify their specific ethical perspective, but from the professed ethos of their schools one can assume that the perspective was Christian. The rationale for the sample was that the researchers wanted to obtain information from school principals, learners and parents who were affected by or involved in the 'buying' of learners to improve the image of a school. The ethical aspects to which the researchers adhered included informed consent from the school principals and participants. Reliability was established by using the following tactics as ways to guard against bias in the findings: peer review, two researchers conducting the research and returning the data to participants where there was a lack of clarity about meanings in their responses. The researchers sought to elicit the responses of the participants at a specific time and place and in a specific interpersonal context. Thus, qualitative researchers may celebrate the richness and depth of data that can be obtained from participants who has been purposely approached (Savin-Baden \& Fisher 2002:191). The researchers aimed at reporting the participants' viewpoints, thoughts, intentions and experiences accurately by making use of direct quotations in the findings.

Data were gathered using a questionnaire according to a qualitative research approach, with semi-structured and openended questions. The questionnaire was not standardised and the findings cannot be generalised. Furthermore, the study was limited because the sample selection included only Gauteng participants. The intention was to elicit the participants' views on the ethical and educational issues that arise when learners are 'bought'.

A printed questionnaire with seven semi-structured and three open-ended questions was sent to the participants. Leedy and Ormrod (2001:197) state that when a questionnaire is used, participants can respond to questions with the assurance that their responses will be anonymous, and so they are more honest than they would be during a personal interview. Data were hand-coded for internal consistency (Haig 1995). The questions included biographic information and elicited views on the type of learner, how learners were approached by schools, the relationship between these learners and others, ethical issues regarding the power of money and long-term and psychological implications.

The following questions were raised: What ethical example is set to learners when adults apply financial power to promote the image of a school? What educational dilemmas are presented when learners with special talents are more welcome in a school than others whose achievements are not on the same level? What are the long-term effects and psychological impact on learners who are 'taught' that 'anything can be bought'? What impact will it have on them when they go to university? Do they regard themselves as superior to other learners and do the other learners experience themselves as inferior? Do parents act ethically when they put a price on their talented children?

The analysis and interpretation of data were approached in four stages. In stage 1, keywords in all the responses were identified, and in stage 2, the keywords were segmented into categories. In stage 3 , the categories were consolidated into themes, and in stage 4 , the themes were interpreted within the theoretical framework discussed in a previous section above. This evaluation enabled the researchers to 
form an idea of the current ethical stance or values of school principals, parents and learners. Findings are presented and discussed in the next section.

\section{Findings and discussion}

The data rendered useful information for the authors to classify the participants' viewpoints and to evaluate their responses.

\section{Perceptions of school principals}

The biographic details of participating school principals are set out in Table 1.

The school principals' perceptions of the ethical example set to learners when adults use their financial power to promote the image of a school were unanimous. Participant A said he believed it would be unethical to 'buy' learners to promote the image of the school. If a school did that, it meant that the school did not have confidence in itself to be successful. According to this participant, principals from well-resourced schools that 'bought' learners wanted to boost their own ego and gain more status. Participant B was very adamant in his view, namely that it would be absolutely unethical and incompatible with educational values and norms to 'buy' learners to promote the image of the school. Participant C added that such transactions contributed to materialism. The learners involved would come to think that success is measured in terms of money. Participants B and C agreed that 'buying' learners from other schools deprived other learners in their schools of opportunities.

From a utilitarian approach, these responses are all praiseworthy since 'buying' learners does not promote the greatest good for the greatest number. Furthermore, if learners are 'bought', they could become materialistic and think that success in life can be 'bought'. These responses also link with the ethical problem solving approach (Velasquez-Dirksen et al. 2011:2-4). According to the ethical problem solving approach, the following question should be asked: Which course of action develops moral virtues? One can then question the ethical example set to learners when parents and school principals agree to use money to favour some learners above others.

The participating school principals also had to identify ethical implications for learners who are advantaged by the power of money, namely those who are 'bought'. Both participants $\mathrm{A}$ and $\mathrm{B}$ reported that character is built by values and norms, and character determines a learner's success or failure. Money does not guarantee success. Participants added that learners were introduced to a world that differed substantially from the real world they would enter after school. There will

TABLE 1: Biographic details of participating school principals.

\begin{tabular}{lllll}
\hline School Principal & Gender & Age & Province & Experience \\
\hline A & Male & $50-54$ & Gauteng & $25-29$ \\
B & Male & $50-54$ & Gauteng & $25-29$ \\
C & Male & $55-59$ & Gauteng & $30>$ \\
\hline
\end{tabular}

not always be people who sponsor you to be successful in life. Participant $C$ emphasised that learners might become materialistic in later life and neglect real moral virtues which enable us to live and to act ethically. They enable us to pursue the ideals of integrity, fairness, self-control and prudence. Thus, the responses of the participants reflect the principles of the virtue approach (Velasquez-Dirksen et al. 2011:2-4).

Participants were asked to give their views on the psychological impact of being 'bought' on the learners themselves. Participant A indicated that learners might think that the school owed them gratitude because they could have accepted better offers from other schools. On the other hand, the demand to perform could be exhausting and could lead to burnout. Participant B was of the opinion that learners who had been 'bought' regarded themselves as superior to others. They could become bullies, disrespectful and disregardful of authority. Participants B and C said they had experienced that some learners became arrogant. Participant $\mathrm{C}$ also believed that the learners involved might lack sound motivation as their place in a team, for example, was assured.

These responses are in accordance with the virtue approach (Velasquez-Dirksen et al. 2011:2-4). The fact that participants $B$ and $C$ believed that learners that have been 'bought' view themselves as superior to other learners and assume that the school owes them certain privileges because they have special talents point to the fairness and virtue approaches. One should reflect on broad questions concerning the kind of society we want to become, and how we are to achieve that society. Furthermore, to be disrespectful, to bully other learners and to disregard authority are aspects that can be judged to be wrong as these aspects are contrary to specific virtues. In this way, it links with the virtue approach (Velasquez-Dirksen et al. 2011:2-4). The task of an educator is to educate learners to act according to ethical values in order to develop humanity. Virtues such as integrity, respect for others and authority are habits that become characteristics of a person. A person who has developed these virtues will become a virtuous person who will act in an ethical way.

The school principals' perceptions of the psychological impact on learners who were unable to meet expectations and fulfil promises were revealed by two participants. Participant A said that some learners would lose their bursaries, status and places in a team. Participant B said that the impact could be severe. He used the retrenchment of adult workers as an example: Like adults who have been retrenched, learners who failed to meet expectations and lost their status would become depressed, feel rejected and have a negative self-image. They might even consider suicide. These emotions should never be underestimated.

\section{Perceptions of learners}

The biographic details of the learners who participated were obtained and set out in Table 2.

Three of the learners (participants C, E and F) had been 'bought' and three were not. The following points describe the profiles of these learners: Dux learner, one of the top 10 
learners, member of the Youth Council, member of Northern Gauteng rugby team, member of Craven Week rugby team, member of Gauteng chess team, head boy in Grade 7, member of the inter-high athletics team, member of the Junior City Council, member of the first hockey team.

The three 'bought' learners were asked how schools had approached them. They all said that a specific school principal or head of department made an appointment with their parents to discuss their possible future in the school. Incentives like free school fees and sports bursaries were offered. Free accommodation in boarding schools was also offered, and learners were also offered money to attend a specific sports school. The learners also had to indicate for which specific performance they had been 'bought', for example sports, academic, cultural or others. Learners had in most cases been 'bought' for their participation in sports.

The participants' opinions about the ethical example set by adults who use money to recruit specific learners and their views on the long-term effects of such transactions on learners varied. Participant B indicated that the illusion was created that talent and the image of the school could be exchanged for money. According to participant A, he was against the practice, but it was necessary to improve the image of their school and to perform better against other schools. Participant D agreed that it created the idea that 'money could solve problems'. Participants E and F did not have a problem with this practice; they agreed that it helped their parents financially and gave them better opportunities.

The participants were also asked whether they thought these learners felt superior to other learners. Four of the six participants, including some who had been 'bought', said yes. In their motivation, participants said that they felt that these learners had certain privileges that other learners did not have and that they might have an 'attitude'.

The participants' reflections on whether money could be used to achieve specific aims echoed one another. Most of the participants agreed that money was not everything; according to participant $\mathrm{D}$, it could not 'buy' happiness. One participant was very unhappy at his boarding school. He was far from home, he had to meet high expectations and he said he was under a lot of pressure.

\section{Perceptions of parents}

The biographic details of the parents that participated in the study are set out in Table 3 .

Participant A's child had not been 'bought', and participant B's child had been 'bought' by a school about 10 kilometres from home.

Parents were asked to describe their child's achievements and personality. Participant A described his son as positive, with an academic average of $88 \%$. He participated in sports (first hockey and cricket teams), was an athlete, served on
TABLE 2: Biographic details of learners who participated.

\begin{tabular}{llll}
\hline Learners & Gender & Age & Province \\
\hline A & Male & 16 & Gauteng \\
B & Female & 17 & Gauteng \\
C & Male & 15 & Gauteng \\
D & Female & 17 & Gauteng \\
E & Male & 17 & Gauteng \\
F & Female & 16 & Gauteng \\
\hline
\end{tabular}

TABLE 3: Biographic details of parents who participated.

\begin{tabular}{llll}
\hline Parents & Gender & Age & Province \\
\hline A & Male & 52 & Gauteng \\
B & Female & 55 & Gauteng \\
\hline
\end{tabular}

the Junior City Council and Youth Council, and respected other cultures with Christian values. Participant B described her son as a very good sportsman: He was a member of the Northern Gauteng and Craven Week rugby teams and the cluster athletics team. His academic average was between $80 \%$ and $90 \%$, and he had been deputy head boy in Grade 7 . In addition, he was popular and had many friends.

The next two questions asked why learners were 'bought' and how the school benefited from the transaction. According to participant $\mathrm{A}$, whose child had not been 'bought', the school he attended enrolled learners who made a positive contribution and achieved good academic results. He also improved the school's image by taking part in sports and cultural activities and by representing the school on the Junior City Council. Participant B pointed out that because her son went to a specific school, other classmates followed. He performed very well in sports activities and that improved the image of the school. Their rugby team improved, and other learners also wanted to join a winning team.

The parents also had to give their opinion about the ethical example set by adults who used money to 'buy' specific learners for a specific school. They furthermore had to give their opinion about the long-term effects on learners who may come to think money can 'buy' privileges. According to participant $\mathrm{A}$, it taught learners that money and power dominated everything. It also taught learners that their God-given talents were used to rise above other learners financially and socially and made them arrogant. $\mathrm{He}$ also pointed out that it protected learners from the real adult world and that it might be one reason why learners emigrated after school - because they could not cope with the reality. Participant B was against the 'buying' of learners in principle, especially when learners were 'paid' to attend a specific school or when children were taken away from their home environment. Schools even build hostels to 'buy' learners from other provinces! She indicated that schools should rather give bursaries or other forms of incentives to motivate learners to perform better.

The parents were also asked about the psychological implications for learners who had been 'bought' and the implications if the learners could no longer meet the performance requirements stipulated in their contracts. 
Participant A wrote that learners learned that they could sell their talents. They learned that their talents could be used to manipulate and intimidate others. This could lead to arrogance and self-centredness where ' $\mathrm{I}$ ' was the most important person. If learners could no longer meet performance expectations, they might feel disappointed in themselves, which could lead to depression. Both participants felt that learners who were 'bought' felt that they were superior to other learners. These learners knew they were special to the school, and they might not know the value of 'giving', because they received so much.

Regarding the ethical value, other learners might perceive the treatment of their more talented peers as unfair. Smaller schools, too, were at a disadvantage because talented learners who lived in the area enrolled in bigger and wealthier schools.

\section{Conclusion}

The study referred to in this article illustrates the different viewpoints of school principals, learners and parents on ethical and educational dilemmas of schools that 'buy' talented learners on the grounds of their achievements in specific sports or their academic and cultural achievements. As an answer to the main aim of the research, namely to determine whether school principals, learners and parents think that it is unethical to 'buy' talented learners, all the school principals and parents agreed that it is unethical and incompatible with ethical values to 'buy' learners. Only the three 'bought' learners, however, agreed with the practice, a reaction which is understandable.

This study revealed that whilst talented learners are given more opportunities in large, wealthy schools, the practice to 'buy' talented learners can lead to discrimination against other learners. In some cases, learners could even be excluded from schools in their areas because these schools are filled to capacity with talented learners that have been 'bought'. Historically, schools' main purpose has been academic teaching and learning. According to the authors, this should still be the main focus, and not sport. Furthermore, 'buying' learners places too much emphasis on winning, rather than on the joy of participation. This might be due to a strong emphasis on competition, which is typical in the materialistic Western worldview and contrary to the Christian worldview. Schools should teach learners that, although it is typical of people to want to be winners, sport is about enjoyment, physical development and the development of various skills. They should learn that those with fewer talents are not inferior and that the more talented learners are not superior.

Although 'bought' learners did not condemn the 'buying' of learners, the responses of principals and parents were encouraging. These responses imply that wider society recognises that 'buying' learners is actually an unethical practice. In South Africa, where truth, integrity, honesty and other ethical values (principles which Christians know were given by God) are not always part of the framework for decision making, the youth must be educated to respect ethical principles and to act accordingly in order to become virtuous persons. It is therefore concluded that the practice of 'buying' learners should be discouraged whilst greater awareness thereof is actively pursued.

\section{Acknowledgements}

We wish to thank Professor Irmild Horn for her assistance in this research project.

\section{Competing interests}

The authors declare that they have no financial or personal relationships which may have inappropriately influenced them in writing this article.

\section{Authors' contributions}

E.D.P. (University of South Africa) and P.M. (University of South Africa) contributed equally in the research and writing of this manuscript.

\section{References}

Agherdien, N., 2009, 'Theoretical frameworks as a guide to knowledge-making', Doctoral thesis, Department of Information and Communication Technologies, University of Johannesburg.

Aristotle, 1989, Metaphysics - Loeb's Classical Library, transl. H. Trednnick, Harvard University Press, Cambridge.

Arrow, K.J., 1971, 'A utilitarian approach to the concept equality in public expenditures', The Quarterly Journal of Economics 85(3), 409-415.

Brady, L., 1990, 'Feeling and valuing; educational imperatives', Hygie 9(2), 12-15.

Brown, C., 1990, Christianity and Western thought: A history of philosophers, ideas and movements from the ancient world to the age of enlightenment, Apollos, Leicester.

Haig, B.D., 1995, 'Grounded theory as scientific method', viewed 08 April 2011, from http://www.eduiuc.edu/EPS/PES-yearbook/95_docs/haig.html

Horn, I., 1996, 'The implications of New Age thought for the quest for truth: A historical investigation', Doctoral thesis, Department of Philosophy of Education, University of South Africa.

Jimenez, M.J., 2008, 'The value of a promise: A utilitarian approach to Contract Law Remedies', UCLA Law Review 56(3), 56-68.

Kant, I., 1970, 'Critique of practical reason', in A. Zweig (ed.), The essential Kant, pp. 295-324, Mentor, New York.

Kohlberg, L., 1971, 'Stages of moral development as a basis for moral education', in C.M. Beck, B.S. Crittenden \& E.V. Sullivan (eds.), Moral education, Newman Press, New York.

Leedy, D.P. \& Ormrod, J.E., 2001, Practical research: Planning and design, 7th edn., Prentice-Hall, New Jersey.

Lewis, C.S., 1946, The abolition of man, or, reflections on education with specia reference to the teaching of English in the upper forms of schools, Godfrey Bles, London.

Maclntyre, A., 1981, After virtue: A study in moral theory, Duckworth, London.

Maduane, K.F., 1992, 'Die relatiewe plek en betekenis van normgehoorsaamheid in die totale beweging van morele opvoeding', Doctoral Thesis, Department of Education, University of South Africa.

McMillan, J.H. \& Schumacher, S., 2006, Research in education: Evidence-based inquiry, 6 th edn., Pearson, Boston.

Oosthuizen, C., 2009, 'Skole, koop eerder wiskunde-onderwysers!' Beeld, 27 December, n.p.

Orwell, G., 1990, Animal farm, Harcourt Brace \& Company, Orlando.

Savin-Baden, M. \& Fisher, A., 2002, 'Negotiating "honesties" in the research process', British Journal of Occupational Therapy 65(4), 191-193.

South African Government, 1996, South African Schools Act, No. 84, viewed 22 March 2011, from http://www.info.gov.za/acts/1996/a84-96:7-8

Velasquez-Dirksen, M., Andre, C., Shanks, T. \& Meyer, M.J., 2011, 'Thinking ethically: A framework for moral decision making', viewed 08 April 2011, from http://www. scu.edu/ethics/ practicing/decision/thinking.html

Wright, L., 1982, 'Approaches to values education', The Canadian School Executive, 2(3), 22-25. 